\title{
Wound healing of the pelvic floor concerning pelvic organ prolapse - What do we know?
}

\author{
Cicatrização do assoalho pélvico e relação com prolapso de órgão pélvico \\ - O que sabemos?
}

\begin{abstract}
Maria Eduarda Furtado Fernandes Terra ${ }^{1}$, Alejandra Maria Ruiz-Zapata ${ }^{2}$, Kirsten B. Kluivers' ${ }^{2}$, Marco N. Helder ${ }^{3}$, Manon H. Kerkhof ${ }^{4}$
\end{abstract}

Terra MEF, Ruiz-Zapata AM, Kluivers KB, Helder MN, Kerkhof MH. Wound healing of the pelvic floor concerning pelvic organ prolapse - What do we know? / Cicatrização do assoalho pélvico e relação com prolapso de órgão pélvico - O que sabemos? Rev Med (São Paulo). 2020 July-Aug;99(4):374-83.

\begin{abstract}
Pelvic organ prolapse (POP) is a result of the pelvic's floor supportive tissues weakening, including levator ani muscles, endopelvic fascia, ligaments, and the vaginal wall. The objective of this review is to describe the wound healing physiology in tissues that might be injured in the pelvic floor and to discuss the factors that affect wound healing. Since the most important risk factors for POP, such as pregnancy, vaginal delivery, and increased intra-abdominal pressure, trigger tissue damage, i.e. a wound in the pelvic floor tissues, we hypothesize that a frustrated wound healing process could affect the tissue homeostasis and promote POP. MEDLINE database was searched to review the literature up to 2017. As with skin, the wound healing in the pelvic floor tissues takes place in four phases (hemostasis, inflammation, proliferation and remodeling), however the duration of each phase is longer in the different structures of the pelvic floor compared to skin. Mechanical loading in the pelvic floor negatively affects healing and is associated with increased collagenase activity, whilst estrogen seems to improve the mechanical properties of the stretched tissue and could be beneficial for vaginal wound healing. Neither damaged muscle, nerves, ligaments nor vaginal wall will fully recover their prewounding characteristics. We postulate that a frustrated wound healing of the tissues of the pelvic floor generates tissues with altered composition and mechanical properties which could lead to the incidence or progression of POP.
\end{abstract}

Key words: Pelvic floor; Wound healing; Pelvic organ prolapse.
RESUMO: O prolapso de órgão pélvico (POP) é resultado do enfraquecimento dos tecidos de sustentação e de suspensão dessa região, incluindo os músculos levantadores do ânus, a fáscia endopélvica, os ligamentos e a parede vaginal. Sabe-se que os fatores de risco mais importantes para o POP, como gravidez, parto vaginal e aumento da pressão intra-abdominal, causam lesão nos tecidos do assoalho pélvico. Assim, é possível que um processo de cicatrização imperfeito desses tecidos possa afetar sua homeostase e contribuir para o desenvolvimento do POP. Dessa forma, o objetivo deste artigo é revisar a fisiologia da cicatrização de tecidos do assoalho pélvico e discutir os fatores que interferem nesse processo. Para isso, foi feita uma revisão da literatura na base de dados do MEDLINE até 2017. Percebeu-se que, assim como na pele, a cicatrização das lesões do assoalho pélvico ocorre em quatro fases (hemostasia, inflamação, proliferação e remodelação), porém a duração de cada fase é maior nas diferentes estruturas do assoalho pélvico. Além disso, a pressão constante no assoalho pélvico está associada ao aumento da atividade da colagenase, afetando negativamente a cicatrização, enquanto o estrogênio melhora as propriedades mecânicas do tecido estirado e parece ser benéfico para a cicatrização das lesões na parede vaginal. De acordo com a literatura, os músculos, nervos, ligamentos ou parede vaginal danificados não recuperam totalmente suas características prévias. Desse modo, conclui-se que uma cicatrização imperfeita no assoalho pélvico resulta em tecidos com composição e propriedades mecânicas alteradas, $o$ que pode levar à incidência ou progressão do POP.

Descritores: Diafragma da pelve; Cicatrização; Prolapso de órgão pélvico.

Oral presentation in Brazilian International Congress of Medical Students (BRAINCOMS), Universidade Federal de São Paulo (UNIFESP), São Paulo, SP, Brazil, 21-23 Out. 2016

1. Federal University of the State of Rio de Janeiro (UNIRIO), Rio de Janeiro, Brazil. ORCID: https://orcid.org/0000-0002-7217-5876. Email: terradudarj@ hotmail.com

2. Department of Obstetrics and Gynecology, Radboud University Medical Center, Nijmegen, The Netherlands. ORCID: Ruiz-Zapata AM - https://orcid. org/0000-0002-7619-2139, Kluivers KB - https://orcid.org/0000-0002-4681-4304. Email: Alejandra.ruizzapata@radboudumc.nl, Kirsten.Kluivers@ radboudumc.nl.

3. Department of Orthopedic Surgery, MOVE Research Institute Amsterdam, VU University Medical Center, Amsterdam, The Netherlands. https://orcid. org/0000-0003-3195-1223. Email: m.helder@vumc.nl

4. Department of Urology, Radboud Institute for Molecular Life Sciences (RIMLS), Radboud University Medical Center, Nijmegen, The Netherlands. ORCID: https://orcid.org/0000-0001-9986-763X. Email: mhkerkhof@freeler.nl

Correspondence: Maria Eduarda Furtado Fernandes Terra. Rua Visconde de Pirajá, 207 / 1502. Ipanema, Rio de Janeiro - RJ, Brasil. CEP $22410-060$. 


\section{INTRODUCTION}

Delvic organ prolapse (POP) is a disorder characterized by the downward displacement of a pelvic organ, such as vagina, uterus, bladder and/or rectum, from its natural anatomic location ${ }^{1}$. This condition affects women's daily activities and decreases their quality of life ${ }^{2}$, which makes POP a growing public health concern worldwide. For example, in the United States alone, over 300,000 prolapse surgeries are performed annually ${ }^{3}$ and the lifetime risk of surgery for POP in the general female population is around $19 \%{ }^{4}$.

POP is a consequence of the weakening of the pelvic floor supportive tissues. The abdominal and pelvic organs are mainly supported through an interaction between the pelvic diaphragm and the endopelvic fascia ${ }^{5}$. The pelvic diaphragm consists of the levator ani muscles and their coverings, whereas the endopelvic fascia forms consists of connective tissue that covers the pelvic organs and forms ligaments responsible for its lifting ${ }^{5,6}$.

Throughout a woman's life, the vaginal wall is constantly being remodeled in response to several stimuli. Parturition is probably one of the most challenging stimuli to induce vaginal tissue remodeling, as it is strongly associated with the incidence of POP. Also, pregnancy itself, previous surgery and increased intra-abdominal pressure due to obesity, chronic constipation, or chronic coughing, are important risk factors for the development of $\mathrm{POP}^{7}$. Micro-injury to the pelvic floor tissues caused by increased intra-abdominal pressure might have the same impact as obstetric injury in the development of pelvic floor damage ${ }^{8}$. This might explain why also nulligravidas can develop POP'.

What all risk factors have in common is that any injury caused by these stimuli triggers a wound healing process that aims to restore the tissue integrity ${ }^{10}$. In addition, the mechanical loading in the pelvic floor caused by the prolapse itself could overstretch the wound and affect the healing process. Therefore, an impaired wound healing process possibly affects the tissue homeostasis. This, in turn, might cause a permanent impairment on the pelvic floor strength that could contribute to the development and progression of POP. Thus, the purpose of this article is to review the current literature regarding wound healing of the pelvic floor supportive tissues and the factors that affect it. This review will help to clarify the physiology of the tissue repair process and the factors affecting wound healing, especially of the soft tissues of the pelvic floor. This knowledge could advance the understanding of extracellular matrix (ECM) abnormalities seen in prolapsed tissues, contribute to the development of treatments in an early stage after wound repair in the pelvic floor, and might lead us towards new preventive strategies.

\section{METHODS}

The primary investigator and a clinical librarian searched the computerized database MEDLINE 2017, using terms such as "pelvic organ prolapse", "uterine prolapse", "cystocele", "rectocele", "pelvic floor", "parturition", "wound healing", "wound repair", "wound closure", "tissue healing", "tissue remodeling", "supportive tissue" and "extracellular matrix". Not only free text terms but also Mesh terms were used. Only data published in full article form were included. Additionally, articles were obtained by reviewing reference lists of pertinent studies and reviews. No articles written in languages other than English provided additional information.

\section{Wound healing physiology}

Wound healing is a biological process that aims to restore tissue integrity after an injury. The wound healing process for skin is well described and has four overlapping phases: hemostasis, inflammation, proliferation, and tissue remodeling ${ }^{10,11}$.

The hemostasis starts with the vascular damage that occurs immediately after an injury. It consists of clot formation and constriction of damaged arterial vessels to avoid blood loss. The clot formation is achieved through three mechanisms: the intrinsic pathway of the clotting cascade (contact activation pathway), the extrinsic pathway of the clotting cascade (tissue factor pathway), and the platelet activation ${ }^{10}$. Besides being responsible for clot formation, platelets produce growth factors and cytokines that regulate the healing cascade ${ }^{10}$. Simultaneously, the constriction of damaged vessels reduces the blood flow and leads to tissue hypoxia and acidosis. This results in the production of vasoactive metabolites, such as nitric oxide and adenosine, which, in addition to histamine released from mast cells, aims to increase dilatation and vascular permeability to facilitate the entry of inflammatory cells into the extracellular space near the wound ${ }^{10}$.

The inflammatory reaction aims to prevent infection and to clear the debris from the wound through the action of neutrophils, macrophages, and lymphocytes ${ }^{10}$. Neutrophils infiltrate the wound within the first 48 hours in response to chemical signals such as the complement cascade, interleukin activation, and transforming growth factor- $\beta$ $(\mathrm{TGF}-\beta)^{10}$. Neutrophils also destroy debris and bacteria through phagocytosis, and by secreting toxic substances and reactive oxygen radicals ${ }^{10}$. Macrophages infiltrate the wound between 48 and 72 hours after injury attracted by chemical stimuli released from platelets and injured cells $^{10}$. Macrophages are a source of growth factors, such as TGF- $\beta$ and epidermal growth factor (EGF), which contribute to stimulate angiogenesis and enhance the formation of granulation tissue. Lymphocytes produce ECM and remodel collagen from 72 to 120 hours after the injury occurs ${ }^{10}$.

Various signaling molecules are produced to 
initiate the proliferation phase, which is characterized by fibroblast migration, deposition of ECM, the genesis of granulation tissue, and epithelialization ${ }^{11}$. Fibroblasts, attracted by factors; such as platelet-derived growth factor (PDGF) and TGF- $\beta^{11}$, appear in the wound around 2 to 4 days after an injury. They proliferate and differentiate into myofibroblasts ${ }^{12}$. Myofibroblasts are "transient" cells characterized by the presence of $\alpha$-smooth muscle actin ( $\alpha$-SMA) in the cytoskeleton and play an important role in wound healing by closing wounds in two ways: (1) by contracting the ECM, and (2) by rapid deposition of repair matrix to fill the gaps within the tissues ${ }^{13}$. The myofibroblasts produce matrix proteins that contribute to the construction of the new ECM such as fibronectin, hyaluronan, "repair" collagens (III and V), and proteoglycans. Besides providing turgor to the tissue, the ECM supplies substratum for cell adhesion and regulates growth, movement, and differentiation of cells $\mathrm{s}^{11}$. Moreover, the granulation tissue is well established by 3 to 5 days after injury and it is characterized by angiogenesis, which is induced by several factors such as vascular endothelial growth factor (VEGF), basic fibroblast growth factor (bFGF), PDGF, and TGF- $\beta^{11}$. The epithelialization consists of migration and proliferation of epidermal cells from the wound edges and it requires a moist environment, adequate nutrition, and bacteriological control ${ }^{11}$. This process is modulated by a number of growth factors, including keratinocyte growth factor (KGF), EGF, and $\mathrm{bFGF}^{11}$.

The last phase of the wound repair in soft tissues is the tissue remodeling of the repair matrix. This process involves wound contraction and continuous synthesis and degradation of collagen ${ }^{11}$. The degradation is achieved by enzymes, mainly matrix metalloproteinases (MMPs), that are produced by fibroblasts, neutrophils, and macrophages. The synthesis and secretion of MMPs are tightly regulated by growth factors, cytokines, and phagocytic stimuli to avoid degradation of essential ECM proteins, which could lead to impaired healing ${ }^{11}$. The main cells and growth factors involved in wound healing are listed in Tables 1 and 2 .

Table 1. Cells involved in wound healing ${ }^{10,11}$

\begin{tabular}{|c|c|c|}
\hline Cell type & Time of action & Function \\
\hline Platelets & Seconds & Thrombus formation; release of inflammatory mediators. \\
\hline Neutrophils & $1-48 \mathrm{~h}$ & $\begin{array}{l}\text { Phagocytosis of bacteria; release of proteolytic enzymes; wound debridement; increase vascular } \\
\text { permeability. }\end{array}$ \\
\hline Keratinocytes & $8 \mathrm{~h}$ & Release of inflammatory mediators; neovascularization. \\
\hline Macrophages & $48-72 \mathrm{~h}$ & $\begin{array}{l}\text { Phagocytosis of bacteria; wound debridement; release of inflammatory mediators; stimulation of } \\
\text { fibroblasts division, collagen synthesis, and angiogenesis. }\end{array}$ \\
\hline Lymphocytes & $72-120 \mathrm{~h}$ & Not clearly defined; may produce cytokines. \\
\hline $\begin{array}{l}\text { Fibroblasts / } \\
\text { Myofibroblasts }\end{array}$ & $120 \mathrm{~h}$ & $\begin{array}{l}\text { Synthesis of granulation tissue; production of ECM components (collagen, fibronectin, hyaluronic } \\
\text { acid, proteoglycans); release of inflammatory mediators. }\end{array}$ \\
\hline
\end{tabular}

Table 2. Growth factors involved in wound healing ${ }^{10,11}$

\begin{tabular}{|c|c|c|}
\hline $\begin{array}{l}\text { Growth } \\
\text { factor }\end{array}$ & Major source & Action \\
\hline VEGF & Platelets, neutrophils. & Stimulates angiogenesis. \\
\hline FGFs & $\begin{array}{l}\text { Fibroblasts, endothelial cells, smooth muscle } \\
\text { cells, macrophages. }\end{array}$ & $\begin{array}{l}\text { Genesis of granulation tissue, fibroblasts and epithelial cells proliferation, } \\
\text { matrix deposition, wound contraction, angiogenesis. }\end{array}$ \\
\hline KGFs & Fibroblasts. & Proliferation and migration of keratinocytes. \\
\hline EGF & Platelets, macrophages, keratinocytes. & Formation of granulation tissue, proliferation, and migration of keratinocytes. \\
\hline PDGF & $\begin{array}{l}\text { Platelets, fibroblasts, macrophages, } \\
\text { endothelial cells. }\end{array}$ & $\begin{array}{l}\text { Chemotaxis, the proliferation of fibroblasts, smooth muscle cells, and } \\
\text { endothelial cells, collagen deposition. }\end{array}$ \\
\hline G-CSF & Monocytes, fibroblasts, lymphocytes. & $\begin{array}{l}\text { Proliferation of keratinocytes, enhances function of neutrophils, and } \\
\text { monocytes. }\end{array}$ \\
\hline GM-CSF & $\begin{array}{l}\text { Keratinocytes, macrophages, lymphocytes, } \\
\text { fibroblasts. }\end{array}$ & Proliferation of epidermal cells. \\
\hline TGF- $\alpha$ & Macrophages, platelets. & Proliferation of epithelial cells and fibroblasts, genesis of granulation tissue. \\
\hline TGF- $\beta$ & $\begin{array}{l}\text { Platelets, macrophages, fibroblasts, } \\
\text { neutrophils. }\end{array}$ & $\begin{array}{l}\text { Chemotaxis, differentiation of fibroblasts to myofibroblasts, stimulate } \\
\text { angiogenesis, collagen metabolism, wound contraction, release of other growth } \\
\text { factors, stimulates MMP. }\end{array}$ \\
\hline IL-1 & Macrophages, lymphocytes, platelets. & Chemotaxis, proliferation of fibroblasts. \\
\hline TNF- $\alpha$ & Platelets. & Chemotaxis, nitric oxide release, activation of other growth factors. \\
\hline IGF-1 & Fibroblasts, plasma, liver. & Proliferation of fibroblasts, synthesis of collagen, and proteoglycans. \\
\hline HGF & Fibroblasts, keratinocytes, endothelial cells. & Re-epithelialization, neovascularization, formation of granulation tissue. \\
\hline
\end{tabular}

VEGF: vascular endothelial growth factor; FGFs: fibroblast growth factors; KGFs: keratinocyte growth factors; EGF: epidermal growth factor; PDGF: platelet-derived growth factor; G-CSF: granulocyte-colony stimulating factor; GM-CSF: granulocyte macrophage-colony stimulating factor; TGF- $\alpha$ : transforming growth factor- $\alpha$; TGF- $\beta$ : transforming growth factor- $\beta$; IL-1: interleukin-1; TNF- $\alpha$ : tumor necrosis factor- $\alpha$; IGF-1: insulin-like growth factor; HGF: hepatocyte growth factor. 
Terra MEF, et al. Wound healing of the pelvic floor concerning pelvic organ prolapse - What do we know?

In the pelvic floor, pelvic organ support could be impaired due to micro- or macro- injuries of the levator ani muscle, the nerves, the endopelvic fascia, the suspending ligaments, and/or vaginal wall ${ }^{14-16}$. Injury to these different tissue types triggers a specific wound healing process ${ }^{17}$.

\section{Wound healing of the different structures of the pelvic floor}

\section{Muscle}

The healing of a muscle injury has similar overlapping phases to the skin but with longer durations: destruction (1-3 days), repair (3-4 weeks), and remodeling (3-6 months $)^{18,19}$. The destruction phase consists of rupture and necrosis of the myofibers, formation of hematoma, and inflammation ${ }^{18}$. The repair phase is characterized by phagocytosis of the necrotic tissue, regeneration of the myofibers, capillary ingrowth in the wound, and production of a connective tissue scar ${ }^{18}$. The remodeling phase includes maturation of the myofibers, contraction and reorganization of the scar tissue, and recovery of muscle functional capacity ${ }^{18}$.

Muscle healing is a slow process that may result in incomplete functional recovery ${ }^{20}$. The main cause of suboptimal muscle repair is fibrosis ${ }^{19}$, which is an abnormal and unresolvable chronic increase of ECM that affects tissue function ${ }^{21}$. The presence of fibrotic tissue restricts the regeneration of myofibers and reduces the elasticity of the native muscle and thus, reinjury may occur ${ }^{20}$.

In a rat model, Kääriäinen et al. ${ }^{22}$ observed that the muscle did not reach complete functional recovery by 56 days after laceration injury. Furthermore, in a study with 68 women, Miller et al. ${ }^{23}$ found that levator injury from childbirth did not solve 8 months postpartum. Similarly, Shek et al. ${ }^{24}$ assessed women's pelvic floor 3 to 6 months and 2 to 3 years postpartum and found no evidence of regression of pregnancy- and childbirth-related changes to levator distensibility. These data suggest that levator ani may not recover completely after trauma. Additionally, the muscle functional recovery depends on its reinnervation ${ }^{25}$, since non-innervated muscles may undergo degenerative morphological and biochemical changes ${ }^{26}$ associated with gradual atrophy ${ }^{27}$.

\section{Nerve}

Nerve repair depends on the extent of the injury ${ }^{28,29}$. During labor, nerve injury occurs because of stretching and compression $^{14}$. Based on Seddon ${ }^{30}$ classification (Table 3), nerve compression is likely to fit in the neuropraxia group of nerve injuries ${ }^{28}$. Neuropraxia is the mildest type of nerve injury, which consists of local myelin damage with no loss of axon continuity ${ }^{30}$. In this case, the nerve does not undergo distal degeneration and there might be a transient functional loss ${ }^{28,31}$. Complete recovery is likely to occur within weeks to months ${ }^{28}$.

Table 3. Seddon ${ }^{30}$ nerve injury classification

$\begin{array}{ll}\text { Neuropraxia } & \text { Local myelin damage, no axon disruption. } \\ \text { Axonotmesis } & \begin{array}{l}\text { Axon disruption, variable preservation of } \\ \text { the surroundings connective tissue. }\end{array} \\ \text { Neurotmesis } & \begin{array}{l}\text { Complete disruption of the entire nerve } \\ \text { trunk. }\end{array}\end{array}$

Research on pudendal nerve injury and regeneration after childbirth has been related to its association with stress urinary incontinence (SUI). Most of the available data comes from external urethral sphincter (EUS) electromyography (EMG) and urethral leak-point pressure (LPP) assessment. According to recent studies conducted in rats, functional recovery after pudendal nerve crush (PNC) could be observed from 2 to 3 weeks after injury ${ }^{32,33}$, although the neuroregenerative process seemed to be near completion only after 6 weeks ${ }^{32}$.

However, if PNC and vaginal distension (VD) were performed together (PNC+VD), which better simulates the injuries from vaginal delivery ${ }^{33}$, the functional recovery seems to occur slower than PNC or VD alone, without complete recovery 6 weeks after injury ${ }^{33}$. The delayed neuroregeneration in this case may be explained by an insufficient upregulation of neurotrophins due to the muscle damage associated with $\mathrm{VD}^{33}$. In a study with 96 women, Allen et al. ${ }^{34}$ found that vaginal delivery causes partial denervation of the pelvic floor in most women, and the pudendal nerve conduction tests showed no significant differences between the puerperium and 2 months postnatally. Furthermore, a study with rats ${ }^{35}$ showed incomplete EUS neuromuscular innervation 9 weeks after PNC+VD despite functional recovery, which suggests a persistent neurogenic deficiency.

\section{Endopelvic fascia and ligaments}

After significant denervation or overstretching of the tissues of the pelvic floor, women might develop POP especially when there is a pre-existing weakness of ligaments and fascia ${ }^{36}$. The ligaments and fascia of the pelvic floor differ from those from other sites in the body because they are visceral connective tissue elements, more related to organ function than to locomotion ${ }^{36}$. Unfortunately, 
much of the current knowledge about connective tissue is derived from orthopedic and sports medicine research ${ }^{36}$, and the healing characteristics might be different between different ligaments ${ }^{37}$. Hence, we should bear in mind that only some of the current knowledge might apply to pelvic floor connective tissues.

With ligaments, wound healing is similar to the general wound healing process but with longer duration. Hemostasis and inflammation might take days to weeks; whilst matrix production may last weeks to months; and remodeling, months to years ${ }^{37}$. These timings could vary depending on the ligaments' size and on the mechanical forces applied to it during healing ${ }^{36}$.

Several studies suggest that ligament healing results in weaker scar tissue, due to different biomechanical composition and structural organization ${ }^{37,38}$. In the early repair of the ligament tear, there are more collagen types III, V, and VI, besides less type I collagen than in the original tissue ${ }^{38}$. As the scar matures, collagen type I production increases and gradually replaces the weaker ones $^{38}$. Moreover, a better alignment of the collagen fibers occurs and an improvement in collagen fibers orientation is likely to increase the tissue tensile strength ${ }^{39}$. A long-term study assessing rabbits' medial collateral ligament showed that the scar tissue quality seems to improve 2 years after injury ${ }^{40}$. Afterwards, no further improvement seems to be noted and the healed ligament appears to remain weaker and less stiff than normal ${ }^{37,40}$.

Studies of the ligaments from fresh female cadavers showed that the uterosacral ligaments were stiffer than the round ligaments and that the rigidity increased with $\mathrm{age}^{41}$. Others have also reported that parous women had higher stiffness and maximum stress of the uterosacral ligaments than nulliparous women ${ }^{42}$ and that the cardinal and uterosacral ligaments seem to be longer in women with $\mathrm{POP}^{43}$.

\section{Vaginal wall}

The literature on vaginal wall healing is limited. By comparing abdominal skin vs. vaginal wall surgical wound healing, a study conducted on rabbits showed that apart from a fibrinous crust, which was evident in the abdominal skin but not in the vagina between 4 to 7 days after injury, most of the histological parameters did not differ significantly between both tissues ${ }^{44}$. However, the vaginal wound seemed to close and contract faster than the abdominal skin wound ${ }^{4}$. This might be due to the inherent and environmental differences between these tissues: (1) higher vascularization in the vagina; (2) keratinized epithelium in skin vs. non-keratinized epithelium in the vagina; (3) possible different concentrations of growth factors; (4) wound unexposed to air and in a moist environment in the vagina, vs. wound exposed to air and in a dryer environment in the skin; (5) different bacterial flora between tissues ${ }^{45}$. Abramov et al. ${ }^{45}$ hypothesized that the faster wound contraction rate in the vagina could be due to the different mechanical forces applied to these tissues in the resting state, or due to distinct levels of myofibroblasts activity, possibly related to a distinct expression of/or response to TGF- $\beta 1$.

Studies conducted on rabbits showed that TGF- $\beta 1^{46}$ and PDGF-B mRNA ${ }^{47}$ expression play a role in cutaneous and vaginal wound healing. However, it was also shown that oophorectomised rabbits have protracted vaginal wound healing associated with increased TGF- $\beta 1$ transcription, suggesting that overexpression of this factor may lead to delayed vaginal wound healing ${ }^{46}$. TGF- $\beta 1$ promotes fibroblast to myofibroblast differentiation and plays an important role in abnormal fibrotic conditions ${ }^{13}$. Studies with fibroblasts from prolapsed vaginal wall tissues have shown that these cells have lower contractile capacities $^{48}$, altered mechanoresponses ${ }^{48,49}$, lower responses to TGF- $\beta 1^{49}$, and altered matrix production ${ }^{50}$. The relation between TGF- $\beta 1$ and POP, if any, still needs to be elucidated.

An assessment of the biomechanical properties of vaginal vs. abdominal surgical wound healing in rabbits showed that neither vaginal nor abdominal tissues had completely recovered their tensile strength and elasticity to pre-wounding values ${ }^{45}$. Indeed several studies have shown that anterior vaginal tissues from women with POP have altered ECM composition ${ }^{6,51-54}$ and mechanical properties with a higher stiffness than controls ${ }^{55-57}$. Additionally, it has been shown that the vaginal wall of women with POP is more extensible than those without $\mathrm{POP}^{58}$, probably due to the variations in collagen and elastin metabolism. The protracted extensibility was associated with increased the severity of $\mathrm{POP}^{58}$. Another study concluded that vaginal parity resulted in decreased collagen alignment and progression to inferior mechanical properties, which were highly correlated with $\mathrm{POP}^{59}$. Kim et al. ${ }^{60}$ provided evidence that POP tissues possess a non-stretchable and fragile collagen matrix with reduced load-bearing capability due to collagen fibrils that are stiffer, bulkier, and with decreased braiding.

A summary of wound healing parameters on the different structures of the pelvic floor is found in Table 4 . 
Terra MEF, et al. Wound healing of the pelvic floor concerning pelvic organ prolapse - What do we know?

Table 4. Wound healing parameters on the different structures of the pelvic floor

\begin{tabular}{|c|c|c|c|c|}
\hline Parameter & Muscle $^{18,19}$ & Nerve 28,31 & $\begin{array}{l}\text { Endopelvic fascia and } \\
\text { ligaments }^{37,38,61}\end{array}$ & Vaginal wall ${ }^{44,45,47}$ \\
\hline Timing & $\begin{array}{l}\text { Destruction: } 1 \text { to } 3 \text { days; } \\
\text { Repair: } 3 \text { to } 4 \text { weeks; } \\
\text { Remodeling: } 3 \text { to } 6 \\
\text { months. }\end{array}$ & $\begin{array}{l}\text { Weeks to many } \\
\text { months. }\end{array}$ & $\begin{array}{l}\text { Hemostasis and } \\
\text { inflammation: days to } \\
\text { weeks; } \\
\text { Proliferation: weeks to } \\
\text { months; } \\
\text { Remodeling: months to } \\
\text { years. }\end{array}$ & Approximately one month. \\
\hline Cells & $\begin{array}{l}\text { Neutrophils, } \\
\text { macrophages, fibroblasts, } \\
\text { myofibroblasts, satellite } \\
\text { cells, myoblasts. }\end{array}$ & $\begin{array}{l}\text { Schwann cells, } \\
\text { macrophages, mast } \\
\text { cells, fibroblasts. }\end{array}$ & $\begin{array}{l}\text { Neutrophils, macrophages, } \\
\text { fibroblasts, myofibroblasts. }\end{array}$ & $\begin{array}{l}\text { Neutrophils, macrophages, } \\
\text { fibroblasts, myofibroblasts, } \\
\text { smooth muscle cells. }\end{array}$ \\
\hline GF & $\begin{array}{l}\text { TNF- } \alpha, \text { FGF, IGF, TGF- } \beta \text {, } \\
\text { HGF, PDGF, EGF, VEGF. }\end{array}$ & $\begin{array}{l}\text { NGF, BDNF, ciliary } \\
\text { neurotrophic factor, } \\
\text { FGF, IGF. }\end{array}$ & $\begin{array}{l}\text { IGF-I, TGF- } \beta \text {, VEGF, } \\
\text { bFGF, EGF, PDGF. }\end{array}$ & VEGF, TGF- $\beta$, PDGF, \\
\hline ECM & $\begin{array}{l}\text { Fibronectin, tenascin-C, } \\
\text { followed by collagen III } \\
\text { and collagen I. }\end{array}$ & $\begin{array}{l}\text { Laminin with collagen } \\
\text { IV, proteoglycan and } \\
\text { entactin; fibronectin } \\
\text { and fibrinogen. }\end{array}$ & $\begin{array}{l}\text { Increased amount of } \\
\text { minor collagens (types } \\
\text { III, V, and VI), decreased } \\
\text { collagen cross-links, } \\
\text { increased amount of } \\
\text { glycosaminoglycans. }\end{array}$ & $\begin{array}{l}\text { Collagen deposition } \\
\text { increases until } \\
\text { postwounding day } 35 \text {. }\end{array}$ \\
\hline
\end{tabular}

GF: growth factors; ECM: extracellular matrix; TNF: tumor necrosis factor; FGF: fibroblast growth factor; IGF: insulin-like growth factor; TGF: transforming growth factor; HGF: hepatocyte growth factor; PDFG: platelet derived growth factor; EGF: epidermal growth factor; VEGF: vascular endothelial growth factor; NGF: nerve growth factor; BDNF: brain-derived neurotrophic factor.

\section{Factors affecting wound healing}

Wound healing is a complex process that depends on a precise integration between its phases of hemostasis, inflammation, proliferation, and remodeling. Some factors can interfere in one or more phases of the process, leading to improper or impaired tissue repair ${ }^{62}$. These factors are summarized in Table 5.

Table 5. Factors affecting wound healing

\begin{tabular}{|c|c|}
\hline Factor & Action \\
\hline Oxygen & $\begin{array}{l}\text { regulates some GF production (TGF- } \beta \text {, VEGF); induces angiogenesis, fibroblast proliferation, and collagen } \\
\text { synthesis; prevents infection through oxidative killing }{ }^{75} \text {. }\end{array}$ \\
\hline Infection & $\begin{array}{l}\text { upregulates pro-inflammatory cytokines (IL-1, TNF- } \alpha \text { ) and increase levels of MMPs, which may result in } \\
\text { excessive degradation of ECM and impaired healing }{ }^{62,76} \text {. }\end{array}$ \\
\hline Age & $\begin{array}{l}\text { leads to enhanced platelet aggregation, increased levels of inflammatory mediators, delayed infiltration } \\
\text { of macrophages and lymphocytes, impaired macrophage function, reduced levels of GF, delayed re- } \\
\text { epithelialization, delayed angiogenesis and collagen deposition, decreased collagen turnover, and } \\
\text { remodeling, reduced wound strength }{ }^{77} \text {, slower healing }\end{array}$ \\
\hline Obesity & $\begin{array}{l}\text { increases risks of complications (infection, dehiscence, hematoma, seroma, venous ulcer, pressure ulcer) }{ }^{79} \\
\text { due to hypoperfusion and decreased diffusion of antibiotics }{ }^{62} \text {; increases risks of impaired mononuclear cell } \\
\text { function, decreases lymphocyte proliferation, and alters cytokine levels }{ }^{62} \text {. }\end{array}$ \\
\hline Nutrition & $\begin{array}{l}\text { nutrient deficiencies prolong inflammation, inhibit fibroblast function, reduce collagen deposition, and } \\
\text { angiogenesis }{ }^{10} \text {. }\end{array}$ \\
\hline Diabetes & $\begin{array}{l}\text { microvascular damage affects tissue oxygen levels and nutrients supply }{ }^{10} \text {. Diabetic neuropathy } \\
\text { impairs neuropeptides functions: promote cell chemotaxis, induce GF production, and stimulate cell } \\
\text { proliferation }{ }^{62} \text {. }\end{array}$ \\
\hline Alcohol consumption & $\begin{array}{l}\text { impairs early inflammatory response, inhibits wound closure and angiogenesis, inhibits collagen } \\
\text { production, alters protease balance at wound } \text { site }^{62} \text {, and increases the incidence of infection }{ }^{80} \text {. }\end{array}$ \\
\hline Smoking & $\begin{array}{l}\text { decreases wound tensile strength and increases risks of complications (infection, wound rupture, necrosis) } \\
\text { due to tissue hypoxia }{ }^{11,82} \text {. Low doses of nicotine enhance angiogenesis, and may improve healing }{ }^{83,84} \text {. }\end{array}$ \\
\hline Estrogen & $\begin{array}{l}\text { regulates ECM production, protease inhibition, epidermal function, and genes related to regeneration and } \\
\text { inflammation }{ }^{85} \text {. }\end{array}$ \\
\hline Mechanical loa & $\begin{array}{l}\text { inhibits apoptosis in the proliferative wound environment }{ }^{64} \text {, and upregulates expression of genes related } \\
\text { to inflammation and ECM production }{ }^{63} \text {, resulting in an excessive and disorganized accumulation of cells, } \\
\text { and ECM that compromises tissue strength }{ }^{64} \text {. }\end{array}$ \\
\hline
\end{tabular}

GF: growth factor; TGF: transforming growth factor; VEGF: vascular endothelial growth factor; IL-1: interleukin-1; TNF- $\alpha$ : tumor necrosis factor; MMP: metalloproteinase; ECM: extracellular matrix. 
Among those factors, estrogen and mechanical loading are worth mentioning in the context of pelvic floor wound healing. Although an appropriate amount of mechanical tension is necessary for myofibroblast differentiation and consequent wound closure ${ }^{12}$, increased loading negatively affects the healing process (Table 5). Altered mechanical conditions are associated with fibroproliferative diseases and hypertrophy in multiple organ systems (e.g. pulmonary fibrosis, congestive heart failure, glomerulosclerosis ${ }^{63,64}$. However, in the pelvic floor, mechanical stretch is associated with an increased collagenase activity by vaginal fibroblasts ${ }^{65,66}$. Vaginal cells from women with severe POP, in comparison to non-POP controls, react differently to in vitro mechanical stretch, showing downregulation of genes involved in ECM biogenesis and an upregulation of genes involved in ECM biodegradation $^{67}$.

Interestingly, the administration of estrogen could improve the mechanical properties of the stretched connective tissue by inhibiting the degradative behavior of the vaginal fibroblasts ${ }^{65,68}$. Vaginal estrogen application has been shown to promote the synthesis of mature collagen, decrease collagenase activity, and increase the thickness of the vaginal wall ${ }^{69}$, thus appearing beneficial for wound healing ${ }^{70}$. Recent evidence suggests that local estrogen improves vaginal tissue quality in postmenopausal women after vaginal reconstructive surgery ${ }^{71}$. An animal study showed that bilateral oophorectomy and estrogen deficiency result in delayed vaginal wound healing, scar contraction and recovery of biomechanical properties ${ }^{72}$, and was associated with enhanced inflammation ${ }^{73}$. Moreover, the systemic use of estrogen after a surgical injury to guinea pigs leads to greater amounts of collagen and elevated density of elastic fibers, resulting in higher distensibility of the vagina while maintaining its tissue strength ${ }^{74}$.

\section{Are impaired wound healing and POP interlinked?}

POP is a multifactorial disease that occurs as a consequence of the weakening of the pelvic floor supportive tissues. According to literature, POP tissues differ from non-POP tissues in ECM composition ${ }^{6,51-54}$, number and functionality of cells ${ }^{48-50,86,87}$, and amount of growth factors ${ }^{88,89}$. Together, these differences affect the biomechanical properties of POP tissues, which seem to be more extensible, with stiffer matrices and reduced loadbearing capabilities ${ }^{57,58,60}$.

Recent studies correlate POP with an injury of the pelvic floor's soft tissues, such as the levator ani muscle ${ }^{15,90,91}$, the pudendal nerve $\mathrm{e}^{14,92}$, and the paravaginal fascias ${ }^{16,36,93,94}$. These injuries, in turn, seem to be related to parturition, constipation, and higher body mass indexes, which are among the main risk factors for $\mathrm{POP}^{8,9,14,36,95,96}$.
Once an injury occurs, wound healing takes place, aiming to restore tissue integrity. Although the literature on wound healing of the different tissue types of the pelvic floor is scarce, several studies suggest that neither the damaged muscle, nerves, ligaments nor the vaginal wall are able to completely revert to their pre-wounding characteristics $^{22-24,33,35,37,40,45}$.

Hence, the changes in matrix and cells found in POP tissues could be the result of an impaired wound healing. The connective tissue with altered composition and biomechanical properties would thus be a cause of POP. However, it might also be that the remodeling in connective tissues is being triggered by the stretching due to the constant loading of the soft tissues of the prolapse itself, and the alterations are, in fact, a consequence of $\mathrm{POP}^{97,98}$.

Regardless of being a cause or a consequence of POP, changes in POP tissue composition could affect a subsequent wound healing process. Fibroblasts, growth factors, and the ECM likely play an essential role in the proliferation and remodeling phases ${ }^{11}$, and its altered functionality and composition would result in impaired healing. Thus, the improper healing could have an impact on the prognosis of POP, since it would negatively affect recovery after surgical treatment. Perioperative administration of estrogen in postmenopausal women increases synthesis of mature collagen and decreases degradative activity. Leading to an increased thickness of the vaginal wall, which might improve tissue quality postoperatively ${ }^{69,71}$. Identification of other factors which could be beneficial for wound healing on the pelvic floor should be an important topic for future research.

\section{CONCLUSION}

Compared to the skin, the duration of the wound healing process of the different tissues of the pelvic floor is longer. Mechanical loading on the pelvic floor negatively affects healing and is associated with increased collagenase activity, whilst estrogen seems to improve the mechanical properties of the stretched tissues and could be beneficial for vaginal wound healing. Neither damaged muscle, nerves, ligaments nor vaginal wall will fully recover their pre-wounding characteristics. Impaired wound healing of the tissues of the pelvic floor might generate tissues with altered composition and mechanical properties that could lead to the incidence or progression of POP. Further research is needed for better understanding of the wound healing of the different tissues of the pelvic floor, their healing times, and the factors involved to develop strategies to improve tissue quality. Overall, increasing the knowledge of POP's pathophysiology will contribute to improving its clinical management and development of new treatments.

\footnotetext{
Acknowledgments: The authors would like to thank Alan Brind for proofreading the manuscript. M.E.F.F. TERRA acknowledges financial support from a scholarship from the Ministry of Science, Technology, Innovation and Communication of Brazil (CNPq, scholarship No. 234007/2013-3).
} 
Terra MEF, et al. Wound healing of the pelvic floor concerning pelvic organ prolapse - What do we know?

\section{REFERENCES}

1. Haylen BT, Maher CF, Barber MD, Camargo S, Dandolu V, et al. An International Urogynecological Association (IUGA) / International Continence Society (ICS) Joint Report on the Terminology for Female Pelvic Organ Prolapse. Neurourol Urodyn. 2016;35:137-68. doi: https://doi.org/10.1136/bmj. i3853.

2. Jelovsek JE, Barber MD. Women seeking treatment for advanced pelvic organ prolapse have decreased body image and quality of life. Am J Obstet Gynecol. 2006;194:1455-61. doi: https://doi.org/10.1016/j.ajog.2006.01.060.

3. Barber MD. Pelvic organ prolapse. BMJ. 2016;354:i3853. doi: 10.1136/bmj.i3853.

4. Smith FJ, Holman CDAJ, Moorin RE, Tsokos N. Lifetime risk of undergoing surgery for pelvic organ prolapse. Obstet Gynecol. 2010;116(5):1096-100. doi: https://doi.org/10.1097/ AOG.0b013e3181f73729.

5. Al-Badr A, Drutz HP. Pelvic organ prolapse. Geriatr Aging. 2002;5(6). doi: https://doi.org/10.1016/S0140-6736(07)604620.

6. Kerkhof MH, Hendriks L, Brölmann HAM. Changes in connective tissue in patients with pelvic organ prolapse--a review of the current literature. Int Urogynecol J. 2009;20:46174. doi: https://doi.org/10.1007/s00192-008-0737-1.

7. Schaffer JI, Wai CY, Boreham MK. Etiology of pelvic organ prolapse. Clin Obstet Gynecol. 2005;48(3):639-47. doi: https:// doi.org/10.1097/01.grf.0000170428.45819.4e.

8. Amselem C, Puigdollers a., Azpiroz F, Sala C, Videla S, Fernández-Fraga $\mathrm{X}$, et al. Constipation: a potential cause of pelvic floor damage? Neurogastroenterol Motil. 2010;22(2):1504. doi: https://doi.org/10.1111/j.1365-2982.2009.01409.x.

9. Dietz HP, Clarke B. Prevalence of rectocele in young nulliparous women. Aust New Zeal J Obstet Gynaecol. 2005;45(5):391-4. doi: https://doi.org/10.1111/j.1479-828X.2005.00454.x.

10. Young A, McNaught CE. The physiology of wound healing. Surgery. 2011;29(10):475-9. doi: https://doi.org/10.1016/j. mpsur.2011.06.011.

11. Enoch S, Leaper DJ. Basic science of wound healing. Surg. 2005;28:409-12. doi: https://doi.org/10.1016/j. mpsur.2010.05.007

12. Hinz B, Mastrangelo D, Iselin CE, Chaponnier C, Gabbiani $\mathrm{G}$. Mechanical tension controls granulation tissue contractile activity and myofibroblast differentiation. Am J Pathol. 2001;159(3):1009-20. doi: https://doi.org/10.1016/S00029440(10)61776-2.

13. Tomasek JJ, Gabbiani G, Hinz B, Chaponnier C, Brown R a. Myofibroblasts and mechano-regulation of connective tissue remodelling. Nat Rev Mol Cell Biol. 2002;3:349-63. doi: https://doi.org/10.1038/nrm809.

14. Memon $\mathrm{H}$, Handa VL. Pelvic floor disorders following vaginal or cesarean delivery. Curr Opin Obs Gynecol. 2012;29(5):9971003. doi: https://doi.org/10.1097/GCO.0b013e328357628b.

15. Dietz HP, Simpson JM. Levator trauma is associated with pelvic organ prolapse. BJOG An Int J Obstet Gynaecol. 2008;115(8):979-84. doi: https://doi.org/10.1111/j.14710528.2008.01751.x

16. Dietz HP. Pelvic floor trauma following vaginal delivery. Curr Opin Obstet Gynecol. 2006;18:528-37. doi: https://doi. org/10.1097/01.gco.0000242956.40491.1e.

17. Phillips SJ. Physiology of wound healing and surgical wound care. ASAIO J. 2000;46(6):2-5. doi: https://doi. org/10.1097/00002480-200011000-00029.

18. Järvinen T a H, Järvinen TLN, Kääriäinen M, Kalimo $\mathrm{H}$, Järvinen M. Muscle injuries: biology and treatment. Am J Sports Med. 2005;33(5):745-64. doi: https://doi. org/10.1177/0363546505274714.
19. Garg K, Corona BT, Walters TJ. Therapeutic strategies for preventing skeletal muscle fibrosis after injury. Front Pharmacol. 2015;6:87. doi: https://doi.org/10.3389/fphar.2015.00087.

20. Huard J, Li Y, Fu FH. Muscle injuries and repair: current trends in research. J Bone Joint Surg Am. 2002;84-A(5):822-32. doi: https://doi.org/10.3389/fphar.2015.00087.

21. Lieber RL, Ward SR. Cellular mechanisms of tissue fibrosis. 4. Structural and functional consequences of skeletal muscle fibrosis. Am J Physiol Cell Physiol. 2013;305(3):C241-52. doi: https://doi.org/10.3389/fphar.2015.00087

22. Kaariainen M, Kaariainen J, Jarvinen TLN, Sievanen H, Kalimo H, Jarvinen M. Correlation between biomechanical and structural changes during the regeneration of skeletal muscle after laceration injury. J Orthop Res. 1998;16(2):197-206. doi: https://doi.org/10.3389/fphar.2015.00087.

23. Miller JM, Kane Low L, Zielinski R, Smith AR, DeLancey JOL, Brandon C. Evaluating maternal recovery from labor and delivery: bone and levator ani injuries. Am J Obstet Gynecol. 2015;213(2):188.e1-188.e11. doi: https://doi.org/10.1016/j. ajog.2015.05.001.

24. Shek KL, Chantarasorn V, Langer S, Dietz HP. Does levator trauma "heal"? Ultrasound Obstet Gynecol. 2012;40(5):570-5. doi: https://doi.org/10.1002/uog.11203.

25. Andia I, Maffulli N. Muscle and Tendon Injuries: The role of biological interventions to promote and assist healing and recovery. Arthrosc J Arthrosc Relat Surg. 2015;31(5):999-1015. doi: 10.1016/j.arthro.2014.11.024.

26. Lin Y-H, Liu G, Li M, Xiao N, Daneshgari F. Recovery of continence function following simulated birth trauma involves repair of muscle and nerves in the urethra in the female mouse. Eur Urol. 2012;29(6):997-1003. doi: https://doi.org/10.1016/j. eururo.2009.03.020.

27. Rantanen J, Ranne J, Hurme T, Kalimo H. Denervated Segments of Injured Skeletal Muscle Fibers Are Reinnervated by Newly Formed Neuromuscular Junctions. J Neuropathol Exp Neurol. 1995;54:188-94. doi: https://doi.org/10.1097/00005072199503000-00005.

28. Lee SK, Wolfe SW. Peripheral nerve injury and repair. J Am Acad Orthop Surg. 1999;8(4):243-52. doi: https://doi. org/10.1097/00124635-200007000-00005.

29. Stroncek JD, Reichert WM. Indweling neural implants: strategies for contending with the in vivo environment. Boca Raton (FL): CRC Press; 2008. Chap. 1, p3-38. doi: https://doi. org/10.1201/9781420009309.pt1.

30. Seddon H. Surgical disorders of the peripheral nerves. Baltimore: Williams Wilkins; 1972. p.68-88. doi: https://doi. org/10.1136/jnnp.67.2.259c.

31. Burnett MG, Zager EL. Pathophysiology of peripheral nerve injury: a brief review. Neurosurg Focus. 2004;16(5):E1. doi: https://doi.org/10.3171/foc.2004.16.5.2.

32. Damaser MS, Samplaski MK, Parikh M, Lin DL, Rao S, Kerns $\mathrm{JM}$, et al. Time course of neuroanatomical and functional recovery after bilateral pudendal nerve injury in female rats. Am J Physiol Ren Physiol. 2008;293(5):1-18. doi: https://doi. org/10.1152/ajprenal.00176.2007.

33. Jiang H-H, Pan HQ, Gustilo-Ashby MA, Gill B, Glaab J, Zaszczurynski $P$, et al. Dual simulated childbirth injuries result in slowed recovery of pudendal nerve and urethral function. Neurourol Urodyn. 2011;30(1):169-73. doi: https:// doi.org/10.1002/nau.20632.

34. Allen RE, Hosker GL, Smith AR, Warrell DW. Pelvic floor damage and childbirth: a neurophysiological study. Br J Obstet Gynaecol. 1990;97(9):770-9. doi: https://doi. org/10.1097/00006254-199104000-00008.

35. Song Q-X, Balog BM, Kerns J, Lin DL, Sun Y, Damaser MS, et al. Long-term effects of stimulated childbirth injury on function and innervation of the urethra. Neurourol Urodyn. 2015;30(1):169-73. doi: https://doi.org/10.1002/nau.22561. 
36. Peggy A. Norton M. Pelvic Floor Disorders: The role of fascia and ligaments. Clin Obstet Gynecol. 1993;36(4):926-38. doi: 10.1097/00003081-199312000-00017.

37. Frank CB, Hart DA, Shrive NG. Molecular biology and biomechanics of normal and healing ligaments - a review. Osteoarthr Cartil. 1999;7(1):130-40. doi: https://doi. org/10.1053/joca.1998.0168.

38. Hildebrand KA, Frank CB. Scar formation and ligament healing. Surg Biol fr Clin. 1998;41(December):425-9.

39. Gomez MA, Woo SL, Inoue M. Medial collateral ligament healing subsequent to different treatment regimens. Am Physiol Soc. 1989;66(1):245-52. doi: https://doi.org/10.1152/ jappl.1989.66.1.245.

40. Loitz-Ramage BJ, Frank CB, Shrive NG. Injury size affects long-term strength of the rabbit medial collateral ligament. Clin Orthop Relat Res. 1997;(337):272-80. doi: https://doi. org/10.1097/00003086-199704000-00031.

41. Rivaux G, Rubod C, Dedet B, Brieu M, Gabriel B, Cosson M. Comparative analysis of pelvic ligaments: a biomechanics study. Int Urogynecol J Pelvic Floor Dysfunct. 2013;24(1):1359. doi: https://doi.org/10.1007/s00192-012-1861-5.

42. Martins P, Silva-Filho AL, Fonseca AMRM, Santos A, Santos L, Mascarenhas T, et al. Strength of round and uterosacral ligaments: a biomechanical study. Arch Gynecol Obstet. 2013;287(2):313-8. doi: https://doi.org/10.1007/s00404-0122564-3.

43. Luo J, Smith TM, Ashton-Miller J a, Delancey JOL. In Vivo Properties of Uterine Suspensory Tissue in Pelvic Organ Prolapse. J Biomech Eng. 2014;136(February):1-6. doi: https:// doi.org/10.1115/1.4026159.

44. Abramov Y, Golden B, Sullivan M, Botros SM, Miller JJR, Alshahrour A, et al. Histologic characterization of vaginal vs. abdominal surgical wound healing in a rabbit model. Wound Repair Regen. 2007;15:80-6. doi: https://doi.org/10.1111/ j.1524-475X.2006.00188.X.

45. Abramov Y, Webb AR, Miller JJR, Alshahrour A, Botros SM, Goldberg RP, et al. Biomechanical characterization of vaginal versus abdominal surgical wound healing in the rabbit. Am J Obstet Gynecol. 2006;194(5):1472-7. doi: https://doi. org/10.1016/j.ajog.2006.01.063.

46. Abramov Y, Hirsch E, Ilievski V, Goldberg RP, Sand PK. Transforming growth factor betal gene expression during vaginal vs cutaneous surgical wound healing in the rabbit. BJOG An Int J Obstet Gynaecol. 2013;120(2):251-6. doi: https://doi. org/10.1111/j.1471-0528.2012.03447.x.

47. Abramov Y, Hirsch E, Ilievski V, Goldberg RP, Botros SM, Sand PK. Expression of platelet-derived growth factor-B mRNA during vaginal vs. dermal incisional wound healing in the rabbit. Eur J Obstet Gynecol Reprod Biol. 2012;162(2):216-20. doi: https://doi.org/10.1016/j.ejogrb.2012.03.012.

48. Ruiz-Zapata AM, Kerkhof MH, Zandieh-Doulabi B, Brolmann HAM, Smit TH, Helder MN. Functional characteristics of vaginal fibroblastic cells from premenopausal women with pelvic organ prolapse. Mol Hum Reprod. 2014;20(11):1135-43. doi: https://doi.org/10.1093/molehr/gau078.

49. Ruiz-Zapata AM, Kerkhof MH, Zandieh-Doulabi B, Brölmann HAM, Smit TH, Helder MN. Fibroblasts from women with pelvic organ prolapse show differential mechanoresponses depending on surface substrates. Int Urogynecol J Pelvic Floor Dysfunct. 2013;24:1567-75. doi: https://doi.org/10.1007/ s00192-013-2069-z.

50. Ruiz-Zapata AM, Kerkhof MH, Ghazanfari S, ZandiehDoulabi B, Stoop R, Smit TH, et al. Vaginal fibroblastic cells from women with pelvic organ prolapse produce matrices with increased stiffness and collagen content. Sci Rep. 2016;6(November 2015):22971. doi: https://doi.org/10.1038/ srep22971.

51. Alperin M, Moalli PA. Remodeling of vaginal connective tissue in patients with prolapse. Curr Opin Obstet Gynecol.
2006;18(5):544-50. doi: https://doi.org/10.1097/01. gco.0000242958.25244.ff.

52. Söderberg MW, Falconer C, Bystrom B, Malmström A, Ekman $\mathrm{G}$. Young women with genital prolapse have a low collagen concentration. Acta Obstet Gynecol Scand. 2004;83:1193-8. doi: https://doi.org/10.1111/j.0001-6349.2004.00438.x.

53. Zong W, Stein SE, Starcher B, Meyn LA, Moalli PA. Alteration of vaginal elastin metabolism in women with pelvic organ prolapse. Obstet Gynecol. 2011;115(5):953-61. doi: https:// doi.org/10.1097/AOG.0b013e3181da7946.

54. Klutke J, Ji Q, Campeau J, Starcher B, Felix JC, Stanczyk FZ, et al. Decreased endopelvic fascia elastin content in uterine prolapse. Acta Obstet Gynecol. 2008;87(1):111-5. doi: https:// doi.org/10.1097/AOG.0b013e3181da7946.

55. Jean-Charles C, Rubod C, Brieu M, Boukerrou M, Fasel J, Cosson M. Biomechanical properties of prolapsed or nonprolapsed vaginal tissue: Impact on genital prolapse surgery. Int Urogynecol J Pelvic Floor Dysfunct. 2010;21(12):1535-8. doi: https://doi.org/10.1007/s00192-010-1208-z

56. Martins P, Lopes Silva-Filho A, Rodrigues Maciel Da Fonseca AM, Santos A, Santos L, Mascarenhas T, et al. Biomechanical properties of vaginal tissue in women with pelvic organ prolapse. Gynecol Obstet Invest. 2013;75(2):85-92. doi: https:// doi.org/10.1007/s00404-012-2564-3

57. Zhou L, Lee JH, Wen Y, Constantinou C, Yoshinobu M, Omata S, et al. Biomechanical properties and associated collagen composition in vaginal tissue of women with pelvic organ prolapse. J Urol. 2012;188(3):875-80. doi: https://doi. org/10.1016/j.juro.2012.05.017

58. Epstein LB, Graham CA, Heit MH. Systemic and vaginal biomechanical properties of women with normal vaginal support and pelvic organ prolapse. Am J Obs Gynecol. 2007;197(2):165. e1-6. doi: https://doi.org/10.1016/j.ajog.2007.03.040

59. Feola A, Abramowitch S, Jones K, Stein S, Moali P. Parity Negatively Impacts Vaginal Mechanical Properties and Collagen Structure in Rhesus Macaques. Am J Obs Gynecol. 2011;203(6):1-17. doi: https://doi.org/10.1016/j. ajog.2010.06.035.

60. Kim T, Sridharan I, Ma Y, Zhu B, Chi N, Kobak W, et al. Identifying distinct nanoscopic features of native collagen fibrils towards early diagnosis of pelvic organ prolapse. Nanomed Nanotechnol Biol Med. 2016;12(3):667-75. doi: https://doi. org/10.1016/j.nano.2015.11.006.

61. Rizzello G, Longo UG, Petrillo S, Lamberti A, Khan WS, Maffulli $\mathrm{N}$, et al. Growth factors and stem cells for the management of anterior cruciate ligament tears. Open Orthop J. 2012;6:525-30. doi: https://doi.org/10.2174/1874325001206010525

62. Guo S, Dipietro LA. Factors affecting wound healing. J Dent Res. 2010;89(Mc 859):219-29. doi: https://doi. org/10.1177/0022034509359125.

63. Januszyk M, Wong VW, Bhatt KA, Vial IN, Paterno J, Longaker MT, et al. Mechanical offloading of incisional wounds is associated with transcriptional downregulation of inflammatory pathways in a large animal model. Organogenesis. 2014;10(2):186-93. doi: 10.4161/org.28818.

64. Aarabi S, Bhatt K a, Shi Y, Paterno J, Chang EI, Loh S a, et al. Mechanical load initiates hypertrophic scar formation through decreased cellular apoptosis. FASEB J. 2007;21(12):3250-61. doi: https://doi.org/10.1096/fj.07-8218com.

65. Zong W, Jallah ZC, Stein SE, Abramowitch SD, Moali PA. Repetitive mechanical stretch increases extracellular collagenase activity in vaginal fibroblasts. Female Pelvic Med Reconstr Surg. 2011;29(6):997-1003. doi: https://doi. org/10.1097/SPV.0b013e3181ed30d2.

66. Rahn DD, Acevedo JF, Word RA. Effect of vaginal distention on elastic fiber synthesis and matrix degradation in the vaginal wall : potential role in the pathogenesis of pelvic organ prolapse. Am J Physiol Integr Comp Physiol. 2008;9032:1351-8. doi: https://doi.org/10.1152/ajpregu.90447.2008. 
Terra MEF, et al. Wound healing of the pelvic floor concerning pelvic organ prolapse - What do we know?

67. Kufaishi H, Alarab M, Drutz H, Lye S, Shynlova O. Static mechanical loading influences the expression of extracellular matrix and cell adhesion proteins in vaginal cells derived from premenopausal women with severe pelvic organ prolapse. Reprod Sci. 2016;23(8):978-92. doi: https://doi. org/10.1177/1933719115625844.

68. Wang S, Zhang Z, Lü D, Xu Q. Effects of Mechanical Stretching on the Morphology and Cytoskeleton of Vaginal Fibroblasts from Women with Pelvic Organ Prolapse. Int J Mol Sci. 2015;9406-19. doi: https://doi.org/10.3390/ijms16059406

69. Rahn DD, Good MM, Roshanravan SM, Shi H, Schaffer JI, Singh RJ, et al. Effects of preoperative local estrogen in postmenopausal women with prolapse: A randomized trial. J Clin Endocrinol Metab. 2014;99(10):3728-36. doi: https://doi. org/10.1210/jc.2014-1216.

70. Rahn DD, Ward RM, Sanses T V., Carberry C, Mamik MM, Meriwether KV, et al. Vaginal estrogen use in postmenopausal women with pelvic floor disorders: systematic review and practice guidelines. Int Urogynecol J. 2015;26(1):3-13. doi: https://doi.org/10.1007/s00192-014-2554-z.

71. Karp DR, Jean-Michel M, Johnston Y, Suciu G, Aguilar VC, Davila GW. A Randomized Clinical Trial of the Impact of Local Estrogen on Postoperative Tissue Quality After Vaginal Reconstructive Surgery. Female Pelvic Med Reconstr Surg. 2011;17(4):279-89. doi: https://doi.org/10.1097/SPV.

72. Abramov Y, Webb AR, Botros SM, Goldberg RP, Ameer GA, Sand PK. Effect of bilateral oophorectomy on wound healing of the rabbit vagina. Fertil Steril. 2011;95(4):1467-70. doi: https:// doi.org/10.1016/j.fertnstert.2010.08.001.

73. Abramov Y, Golden B, Sullivan M, Goldberg RP, Sand PK. Vaginal incisional wound healing in a rabbit menopause model: a histologic analysis. Int Urogynecol J Pelvic Floor Dysfunct. 2012;23(12):1763-9. doi: https://doi.org/10.1007/s00192-0121793-0.

74. Balgobin S, Montoya TI, Shi H, Acevedo JF, Keller PW, Riegel M, et al. Estrogen alters remodeling of the vaginal wall after surgical injury in guinea pigs. Biol Reprod. 2013;89(October):138. doi: 10.1095/biolreprod.113.112367.

75. Bishop A. Role of oxygen in wound healing. J Wound Care. 2008;17(9):399-402. doi: https://doi.org/10.12968/ jowc.2008.17.9.30937.

76. Menke NB, Ward KR, Witten TM, Bonchev DG, Diegelmann RF. Impaired wound healing. Clin Dermatol. 2007;25(1):19-25. doi: https://doi.org/10.1016/j.clindermatol.2006.12.005.

77. Gosain A, DiPietro LA. Aging and wound healing. World J Surg. 2004;28(3):321-6. doi: https://doi.org/10.1007/s00268003-7397-6.

78. Engeland CG, Bosch JA, Cacioppo JT, Marucha PT. Mucosal wound healing: the roles of age and sex. Arch Surg. 2006;141(12):1193-7; discussion 1198. doi: https://doi. org/10.1001/archsurg.141.12.1193.

79. Wilson JA, Clark JJ. Obesity: impediment to postsurgical wound healing. Adv Skin Wound Care. 2004;17(8):426-35. doi: https:// doi.org/10.1097/00129334-200410000-00013.

80. Szabo G, MandrekarP.A recent perspective on alcohol, immunity, and host defense. Alcohol Clin Exp Res. 2009;33(2):220-32. doi: https://doi.org/10.1111/j.1530-0277.2008.00842.x.

81. Ahn C, Mulligan P, Salcido RS. Smoking-the bane of wound healing: biomedical interventions and social influences. Adv Skin Wound Care. 2008;21(5):227-36; quiz 237-8. doi: https:// doi.org/10.1111/j.1530-0277.2008.00842.x.

82. Chan LKW, Withey S, Butler PEM. Smoking and wound healing problems in reduction mammaplasty: is the introduction of urine nicotine testing justified? Ann Plast Surg. 2006;56(2):111-5. doi: https://doi.org/10.1097/01.sap.0000197635.26473.a2.

83. Jacobi J, Jang JJ, Sundram U, Dayoub H, Fajardo LF, Cooke JP. Nicotine accelerates angiogenesis and wound healing in genetically diabetic mice. Am J Pathol. 2002;161(1):97-104. doi: https://doi.org/10.1016/S0002-9440(10)64161-2.

84. Morimoto N, Takemoto S, Kawazoe T, Suzuki S. Nicotine at a low concentration promotes wound healing. J Surg Res. 2008;145(2):199-204. doi: https://doi.org/10.1016/j. jss.2007.05.031.

85. Hardman MJ, Ashcroft GS. Estrogen, not intrinsic aging, is the major regulator of delayed human wound healing in the elderly. Genome Biol. 2008;9(5):R80. doi: https://doi.org/10.1186/gb2008-9-5-r80.

86. Boreham MK, Wai CY, Miller RT, Schaffer JI, Word RA. Morphometric analysis of smooth muscle in the anterior vaginal wall of women with pelvic organ prolapse. Am J Obstet Gynecol. 2002;187(1):56-63. doi: https://doi.org/10.1067/ mob.2002.124843

87. Takacs P, Gualtieri M, Nassiri M, Candiotti K, Medina CA. Vaginal smooth muscle cell apoptosis is increased in women with pelvic organ prolapse. Int Urogynecol J Pelvic Floor Dysfunct. 2008;19(11):1559-64. doi: https://doi.org/10.1007/ s00192-008-0690-Z

88. Meijerink AM, van Rijssel RH, van der Linden PJQ. Tissue composition of the vaginal wall in women with pelvic organ prolapse. Gynecol Obstet Invest. 2013;75(1):21-7. doi: https:// doi.org/10.1159/000341709

89. Qi X-Y, Hong L, Guo F-Q, Fu Q, Chen L, Li B-S. Expression of transforming growth factor-beta 1 and connective tissue growth factor in women with pelvic organ prolapse. Saudi Med J. 2011;32(5):474-8.

90. DeLancey J, Morgan D. Comparison of levator ani muscle defects and function in women with and without pelvic organ prolapse. Obstet Gynecol. 2007;109(2):295-302. doi: https:// doi.org/10.1097/01.AOG.0000250901.57095.ba.

91. Dietz HP, Steensma AB. The prevalence of major abnormalities of the levator ani in urogynaecological patients. BJOG An Int J Obstet Gynaecol. 2006;113(2):225-30. doi: https://doi. org/10.1111/j.1471-0528.2006.00819.x.

92. Lubowski DZ, Swash M, Nicholls RJ, Henry MM. Increase in pudendal nerve terminal motor latency with defaecation straining. Br J Surg. 1988;75(11):1095-7. doi: https://doi. org/10.1002/bjs.1800751115.

93. Cassadó-Garriga J, Wong V, Shek K, Dietz HP. Can we identify changes in fascial paravaginal supports after childbirth? Aust New Zeal J Obstet Gynaecol. 2015;55(1):70-5. doi: https://doi. org/10.1111/ajo.12261.

94. Nguyen JK. Current Concepts in the diagnosis and surgical repair of anterior vaginal prolapse due to paravaginal defects. Obstet Gynecol Surv. 2001;56(4):239-46. doi: https://doi. org/10.1097/00006254-200104000-00025.

95. Guzmán Rojas R, Wong V, Shek KL, Dietz HP. Impact of levator trauma on pelvic floor muscle function. Int Urogynecol J Pelvic Floor Dysfunct. 2014;25(3):375-80. doi: https://doi. org/10.1007/s00192-013-2226-4.

96. Shek KL, Dietz HP. Intrapartum risk factors for levator trauma. BJOG An Int J Obstet Gynaecol. 2010;117(12):1485-92. doi: https://doi.org/10.1111/j.1471-0528.2010.02704.x.

97. Kerkhof MH, Ruiz-Zapata AM, Bril H, Bleeker MCG, Belien JAM, Stoop R, et al. Changes in tissue composition of the vaginal wall of premenopausal women with prolapse. Am J Obstet Gynecol. 2014;210(2):168.e1-168.e9. doi: https://doi. org/10.1016/j.ajog.2013.10.881.

98. Phillips $\mathrm{CH}$, Anthony F, Benyon C, Monga AK. Collagen metabolism in the uterosacral ligaments and vaginal skin of women with uterine prolapse. BJOG An Int J Obstet Gynaecol. 2005;39-46. doi: 10.1111/j.1471-0528.2005.00773.x.

Submitted: June 26, 2018

Accepted: June 22, 2020 